\title{
Trends in the development of accessibility to civil rights protection
}

\author{
Anna Konstantinovna Sheremetyeva*, Tatyana Leontievna Kalacheva, Natalia Sergeevna \\ Makharadze, Konstantin Borisovich Parfenov, and Antonina Viktorovna Fadeeva
}

Pacific State University, Department of Civil Law and Entrepreneurship, Khabarovsk, Russia

\begin{abstract}
The purpose of the study is to analyze the legal regulations that cover the procedures for resolving disputes without judicial proceedings for their subsequent development and popularization. In the course of the study, in combination with a comprehensive and systematic analysis, the following general scientific cognition methods were used: dialectical, hermeneutic, synthesis, the method of ascending from the abstract to the concrete, the method of generalization and comparison. The results of the study are as follows: justice, being a necessary element of building the rule of law, should be supplemented and improved through alternative ways of resolving conflict situations. The latter shall develop civil jurisdiction and resolve disputes on a highly professional basis. It seemed that the creation of a single procedural form would be a guarantee of the effectiveness of the protection of rights, but in contrast to this idea, there was created a procedural code that regulates administrative jurisdiction. In this regard, it seems promising to develop alternative dispute resolution mechanisms, which are simpler models of protection of violated interests than the court. Therefore, the novelty of the study is in the justification of the need to identify patterns of improving access to legal protection through the use of alternative methods of dispute resolution.
\end{abstract}

Keywords: effectiveness and operation of the law, alternative, access, justice

\section{Introduction}

The existing system of civil rights protection cannot be considered absolutely effective. Judicial protection should be a foundation that ensures the rights of citizens in the event of disputes. However, the existing structure of the judicial authority, in which the competence of each of the courts is determined based on different criteria, affects the availability of legal proceedings, since it makes it difficult to exercise the right to appeal to the court. The creation of a state governed by the rule of law is impossible without achieving a high level of legal consciousness of its citizens. The ability to effectively resolve conflict situations on the basis of the need to respect the interests of all parties to the dispute is a manifestation of the progress of legal consciousness.

\footnotetext{
* Corresponding author: sher198029@,rambler.ru
} 
Resolving disputes without appealing to court is just a vivid example of a developed legal awareness. However, the current opinion that judicial protection is the perfect form in relation to the available alternatives leads to distrust to the latter. The cynicism in our society leads to the denial of correct behaviour by the subjects and, as a result, non-compliance with legal regulations. The belief that laws cannot be enforced is also a condition for rejecting alternative dispute resolution mechanisms or using them to abuse rights. The existence of simplified judicial procedures that facilitate the rapid consideration of cases has also a negative impact on the popularization of alternative procedures.

In the world practice, there are several dozen different types of conciliation procedures, which include negotiation, mediation, arbitration, mediation-arbitration, or med-arb, conciliation, mini-trial, neutral expert fact-finding, ombudsman, private court system and many other similar procedures [1, 2]. In Russia, some of them are used and legally fixed.

Currently, there are all the necessary legal prerequisites for the formation of the desire to apply for a dispute resolution in alternative ways. The list of conciliation procedures in the procedural legislation has also been expanded. However, people are not really interested in resolving the conflict situation outside the court [3]. In this regard, there is a need for a systematic analysis of the legal regulations covering the procedures for resolving disputes outside of court and establishing the significance of these mechanisms in order to overcome the negative and distrustful attitude of the parties to the conflict towards them.

\section{Methods}

In the course of the study, in combination with a comprehensive and systematic analysis, the following general scientific cognition methods were used: dialectical, hermeneutic, synthesis, the method of ascending from the abstract to the concrete, the method of generalization and comparison.

In addition, a number of synthetic, integrative methods of research are used, which are included in the methodology of interdisciplinarity science, which is relevant for modern socio-humanitarian science.

\section{Results}

The objective necessity of introducing conciliation procedures into the Russian legal system is determined by the high level of conflict of persons disputing in the courts. The unwillingness to find a compromise and recognize their contribution to the current situation leads to long lawsuits and increased hostility to each other. In part, this dynamic exists because of a lack of trust between opponents.

Applying to the court involves a quick and timely resolution of the dispute without the consideration of the conflict and interests of the parties, on the basis of existing legal regulations. The parties to the conflict, while pursuing no good goals, can initiate several lawsuits that last a fairly large amount of time. All this leads to rather sad consequences because instead of living effectively, people are forced to be in a stressful situation. The use of mediation techniques, for example, allows one to understand the root cause of a conflict situation and to meet the needs of each participant in the dispute as much as possible.

Certainly, the development of alternatives to litigation will contribute to maintaining law and order without existing punitive measures, since an increase in the number of disputes resolved without trial will be evidence of increased legal awareness and a desire to take responsibility for the actions committed.

The authors have repeatedly pointed out that the judicial process, being less effective in relation to alternative methods, is also a more expensive mechanism of rights protection [4]. 
In Russia, court proceedings are quite affordable in terms of material costs in comparison with other states. This leads to a lot of appeals to the court. In this regard, an increase in the amount of court costs would partly encourage using the other legal options to resolve the conflict.

Of course, a simple increase in the cost of litigation is unlikely to solve all the existing problems, but it shall be considered as one of the contributing factors. An increase in the fees of representatives will have a similar impact. It is clear that highly professional legal assistance can not cost little, but at present, the cost of legal services is not high enough, and many participants in the proceedings deal with it without such investments at all. In civil proceedings, citizens often defend their rights independently without professionals. Consequently, the cult of the judiciary and the lack of understanding of the possibilities of other ways to resolve disputes lead to overloading the courts with sometimes unfounded claims.

\section{Discussion}

From the point of view of the definition, "dispute" and "conflict" are different. For example, according to [5], a dispute is an external manifestation of a conflict, the parties to which mutually express dissatisfaction and make demands [5]. Conflict, in turn, acts as a destructive element for public relations, acting as an abnormal manifestation of behaviour [6].

The dispute, being an external expression of the conflict, can be resolved in the legal field, but the conflict as an internal component remains unresolved even after the dispute is resolved. In this regard, the dispute considered in court does not result in mutual satisfaction from the achieved result among the participants, since the conflict is not resolved. It is clear that the conflict as a component of many legal disputes is not resolved in court. There are only alternative ways to resolve it. The role and importance of alternatives to dispute resolution are often discussed [7].

The need to develop a system of alternative conflict resolution is investigated and proved both from a theoretical and practical perspective [8]. The effectiveness of the mechanisms considered as social regulators that promote a balance of interests is determined in many scientific studies [9]. Many authors have established the relationship between the development of alternatives to dispute resolution and the implementation of access to justice [10].

Researchers state that increasing the number and diversity of relevant dispute resolution institutions and processes has only a positive effect [11]. However, only the legislative consolidation of these procedures can not serve as a basis for their popularization. Thus, some authors-legal scholars have conducted surveys of various social groups, which showed that at best $30 \%$ of respondents have only heard of the concept of alternative dispute resolution, but do not know about its content; not more than $5 \%$ or one person out of 20 respondents of a certain social level - heads of companies - knew about its existence and some features. However, there were also respondents who, despite the fact that they are directly related to law enforcement in the field of labor legislation and have, among other things, a legal education, did not hear or know about the possibilities of an alternative method of resolving legal disputes with the help of an intermediary (mediation procedures) [12].

There should be mentioned a very important point regarding the professionalism of those who use alternative methods, since this is what determines the maximum positive effect of the procedure [13-15].

\section{Conclusion}


Justice is an integral part of any society, and alternative ways of resolving disputes should be part of civil jurisdiction. Justice is often accused of prejudice, so the methods considered are designed to consider the individual nature of the situation and the interests of the disputants as much as possible, which contributes to achieving equity. The autonomy and selfdetermination of the participants in the procedure are its main principles. The purpose of alternatives is to ensure that civil rights protection is accessible.

\section{References}

1. E.I. Nosyreva, Alternative resolution of civil disputes in the United States (Izd-vo voronezhskogo universiteta Publ., 1999)

2. M.N. Kuzmina, Mediation as an alternative form of resolving legal conflicts, in Development of alternative forms of resolving legal conflicts (Saratov, 2000)

3. L.N. Bardin, Yurist, 21, 13-16 (2016)

4. G. Thomas, L. Shenoy, Alternative Methods of Dispute Resolution for Small Businesses. Accessed on: July 8, 2021. [Online]. Available: https://www.researchgate.net/publication/237743767_Alternative_Methods_of_Disput e_Resolution_for_Small_Businesses

5. D.L. Davydenko, Treteyskiy Sud. 1, 40-53 (2009)

6. E.V. Sudorgina, Matters of Russian and International Law, 9(7A), 146-157 (2019)

7. C. O'Neil, FCIArb Dispute Resolution - The Benefits and Risks of Alternative Methods. Accessed on: July 8, 2021. [Online]. Available: https://www.researchgate.net/publication/329870857_Dispute_Resolution__The_Benefits_and_Risks_of_Alternative_Methods. https://doi.org/10.1002/978̄11 $19440345 . \operatorname{ch} 26$

8. K. Hamulakova, J.P. Křiváčková, Alternative Methods of Collective Disputes Resolution in the Czech Republic. Accessed on: July 8, 2021. [Online]. Available: https://www.researchgate.net/publication/309323831_Alternative_Methods_of_Collect ive_Disputes_Resolution_in_the_Czech_Republic. https://doi.org/10.1515/bjes-20160014

9. Z.J. Wang, J. Chen, International Journal of Law in Context, 16(2), 165-180 (2020). https://doi.org/10.1017/S1744552320000129

10. L.A. Ojelabi, M.A. Noone, International Journal of Law in Context, 16(2), 103-107 (2020). https://doi.org/10.1017/S1744552320000087

11. M.A. Noone, L.A. Ojelabi, International Journal of Law in Context, 16(2), 108-127 (2020). https://doi.org/10.1017/S1744552320000099.

12. Yu.V. Darovskikh, Academicheskiy Vestnik, 1, 216-223 (2015)

13. D.Q. Anderson, International Journal of Law in Context, 16(2), 128-145 (2020). https://doi.org/10.1017/S1744552320000105

14. C. Irvine, International Journal of Law in Context, 16(2), 146-164 (2020). https://doi.org/10.1017/S1744552320000117

15. L.A. Ojelabi, J. Gutman, International Journal of Law in Context, 16(2) (2020), 197 215. https://doi.org/10.1017/S1744552320000142 